\title{
Feeding microparticle protein diet combined with Lactobacillus sp. on existence of intestinal bacteria and growth of broiler chickens
}

\author{
M.A. Cholis, N. Suthama* and B. Sukamto \\ Faculty of Animal and Agricultural Science, Diponegoro University, \\ Tembalang Campus, Semarang 50275 - Indonesia \\ *Corresponding E-mail : nsuthama@gmail.com \\ Received February 26, 2018; Accepted March 27, 2018
}

\begin{abstract}
ABSTRAK
Penelitian bertujuan untuk mengevaluasi pengaruh protein mikropartikel dari bungkil kedelai dan tepung ikan yang dikombinasikan dengan Lactobacillus sp. terhadap fisiologis saluran pencernaan dan produktivitas ayam broiler. Materi penelitian adalah 193 ekor broiler, dengan bobot badan awal 481,0 \pm $67,2 \mathrm{~g}$, diberi ransum perlakuan pada hari ke 21 sampai umur 42 hari. Penelitian disusun dalam rancangan acak lengkap (RAL) dengan 8 perlakuan dan 4 ulangan (masing-masing 6 ekor). Perlakuan meliputi : bungkil kedelai dan tepung ikan (tanpa dibuat mikropartikel) $21 \%$ (T0), bungkil kedelai dan tepung ikan (tanpa dibuat mikropartikel) 18\% (T1), protein mikropartikel 21\% (T2), protein mikropartikel 18\% (T3), T0 + Lactobacillus sp. 1,2 mL (T4), T1 + Lactobacillus sp. 1,2 mL (T5), T2 + Lactobacillus sp. 1,2 mL (T6), T3 + Lactobacillus sp. 1,2 mL (T7). Parameter yang diamati adalah total bakteri asam laktat (BAL), populasi Coliform, $\mathrm{pH}$ di ileum, laju digesta, pertambahan bobot badan harian $(\mathrm{PBBH})$ dan bobot karkas. Data diolah dengan analisis ragam dan jika terdapat pengaruh nyata $(\mathrm{P}<0,05)$ dilanjukan dengan uji Duncan. Hasil penelitian menunjukkan bahwa ransum menggunakan protein mikropartikel yang ditambah Lactobacillus sp. $1,2 \mathrm{~mL}$ terjadi peningkatan populasi BAL dan PBBH, namun populasi Coliform menurun serta memperlambat laju digesta, tanpa berpengaruh terhadap bobot karkas. Kesimpulan penelitian adalah pemberian ransum protein mikropartikel terendah (18\%) dengan penambahan Lactobacillus sp. 1,2 $\mathrm{mL}$ (T7) dapat memperbaiki kondisi fisiologis saluran pencernaan berdasarkan populasi BAL dan Coliform serta peningkatkan pertambahan bobot badan harian dengan bobot karkas yang sama.
\end{abstract}

Kata kunci : broiler, Lactobacillus sp., mikroba usus, protein mikropartikel

\begin{abstract}
The objective of the study was to evaluate feeding effect of microparticle protein derived from soybean meal and fish meal combined with Lactobacillus sp. at $1.2 \mathrm{~mL}$ on physiological condition of digestive tract and productivity of broiler. Total of 192 broiler, with initial body weight was $481.0 \pm 67.2$ g, given dietary treatment starting on day 21 until day 42 . The experiment was assigned in a completely randomized design with 8 treatments and 4 replications. Dietary treatment were $21 \%$ intact protein (T0), $18 \%$ intact protein (T1), 21\% microparticle protein (T2), 18\% microparticle protein (T3), T0+Lactobacillus sp.1.2 mL (T4), T1+Lactobacillus sp.1.2 mL (T5), T2+Lactobacillus sp.1.2 mL (T6), T3+Lactobacillus sp.1.2 mL (T7). Parameters measured were total ileal lactic acid bacteria (LAB), Coliform and $\mathrm{pH}$, rate of passage, daily body weight gain (DWG) and also carcass weight. Data were subjected to analysis of variance and followed by Duncan multiple range test $(\mathrm{P}<0.05)$. Experimental results showed that microparticle protein diet added with Lactobacillus $\mathrm{sp}$. $(\mathrm{P}<0.05)$ increased total LAB and DWG, but decreased Coliform population, and slowed down the rate of passage. However, carcass
\end{abstract}


weight was not significantly affected by treatments. Feeding microparticle protein (18\%) with addition of Lactobacillus sp. $(1.2 \mathrm{~mL})$ can improve to be better condition of digestive tract based on higher LAB and lower Coliform populations, and increase daily body weight gain with the same carcass weight.

Keywords: broiler, intestinal microbe, Lactobacillus sp., microparticle protein

\section{INTRODUCTION}

Broiler is a meat type chicken that systematically selected to have high growth rate, therefore, it can achieve high meat production for market in a short raising period. For this purpose, it needs to prepare and serve diet containing high protein to fulfill the bird requirement based on the physiological period and rearing purpose. It is well known that when the diet composed of high source of protein the cost per production unit would be expensive. An effort can be implemented to reduce feed cost that is by lowering the portion of using protein source ingredients. However, the lack of protein supply brings about the consequence of protein deficiency for growing bird. On the other hand, protein supply in term of quantity and quality is the main limiting factor on chicken performance. Costs reduction by lowering dietary protein is a possible way, but it should be anticipated the possibility of low protein intake which can retard growth. Feeding low-protein diet should be accompanied by the efforts of increasing nutrients digestibility, especially proteins, in order to maintain the adequacy of protein supply so that it would not exert a negative effect on productivity. Processing feed component, especially protein source ingredient such as fish meal and soybean meal, to become microparticle protein can ensure high protein digestibility and absorption. Smaller particle sizes can be associated with larger surface area per volume of diet, thus allowing higher digestibility due to the intensive contact with digestive enzyme in poultry (Mingbin et al., 2015)

There were very limited information concerning the study of feeding microparticle protein, but research about particle size of feed ingredients in particular were available elsewhere. Therefore, the present study was conducted to evaluate feeding effect of microparticle diet in broiler chicken. Feeding microparticle protein diet is suggested to be efficient when combined with natural additive such as probiotic Lactobacillus sp. Dietary inclusion of non-antibiotic additives, such as probiotics, have been increasingly important to be applied for poultry productivity improvement. Probiotics can be used as an alternative to antibiotic growth factor because it can produce clean poultry product and consumer health friendly. Feed additives in the form of probiotic Lactobacillus sp. in general provide a positive impact through the decreased intestinal $\mathrm{pH}$ and the increase in population of beneficial bacteria such as lactic acid bacteria (LAB) and lowered total Coliform (Roberfroid et al., 2010).

The development of intestinal microbes, primarily beneficial bacteria, can be affected by diets and nutritional supply, and finally it can promote growth of the animal. Probiotic inclusion into the low protein diet can be applied to be a foundation of developing improved diet in relation to nutrient absorption as well as to prevent poultry from gastrointestinal tract diseases caused by pathogenic bacteria (Pan and $\mathrm{Yu}$, 2014). Research concerning the feeding combination of Lactobacillus sp. and microparticle protein diet has not been much done previously. Smaller particle size of proteins allows more effective absorption, due to an intensive work of digested enzyme supported by the healthy gastrointestinal tract. Therefore, research concerning feeding effect of microparticle protein diet added with Lactobacillus sp. as probiotic was conducted to evaluate their effect on dynamics of intestinal microbe and growth performance in broiler chicken.

\section{MATERIALS AND METHODS}

\section{Experimental Animal and Diet}

The experimental animals used in the present study were 192 birds of day old broiler chicken of Lohman strain with initial body weight of $481.0 \pm$ $67.2 \mathrm{~g}$. Microparticle preparation was performed based on the slightly modified method of Jambrak et al. (2014) using virgin coconut oil as particle stabilisator. Birds were maintained from 1 day to 20 days in a brooder cage given commercial diet, and at 21 days old the chickens were weighed and selected for uniform body weight prior to be moved randomly into the battery cage. The experimental diets (Table 1) were given from day 21 to 42 days old. Lactobacillus sp. was mixed 
Table 1. Composition and Nutritional Content of Experimental Diet

\begin{tabular}{|c|c|c|c|c|}
\hline \multirow[b]{2}{*}{ Ingredient } & \multicolumn{4}{|c|}{ Experimental Diet } \\
\hline & $\begin{array}{c}\text { Intact Protein } \\
21 \%\end{array}$ & $\begin{array}{c}\text { Intact Protein } \\
18 \%\end{array}$ & $\begin{array}{c}\text { Microparticle } \\
\text { Protein } \\
21 \%\end{array}$ & $\begin{array}{c}\text { Microparticle } \\
\text { Protein } \\
18 \%\end{array}$ \\
\hline & \multicolumn{4}{|c|}{ 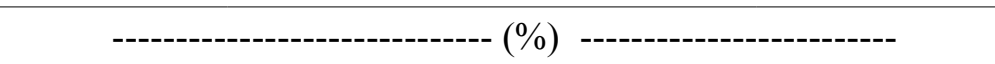 } \\
\hline Yellow corn & 48 & 50.5 & 48 & 50.2 \\
\hline Rice bran & 14 & 20 & 14 & 20 \\
\hline Intact soybean meal & 27 & 21 & - & - \\
\hline Microparticle soybean meal & - & - & 27 & 21 \\
\hline Intact fish meal & 10 & 7.5 & - & - \\
\hline Microparticle fish meal & - & - & 10 & 7.5 \\
\hline $\mathrm{CaCO} 3$ & 0.5 & 0.5 & 0.5 & 0.5 \\
\hline Vitamin and mineral & 0.5 & 0.5 & 0.5 & 0.5 \\
\hline Total & 100 & 100 & 100 & 100 \\
\hline \multicolumn{5}{|l|}{ Nutrient Composition *(\%) } \\
\hline Metabolizable energy $* *(\mathrm{kcal} / \mathrm{kg})$ & 2978.41 & 2948.32 & 2978.41 & 2948.32 \\
\hline Crude protein & 21.29 & 18.12 & 21.29 & 18.12 \\
\hline Ether extract & 2.81 & 2.57 & 2.81 & 2.57 \\
\hline Crude fiber & 4.27 & 4.77 & 4.27 & 4.77 \\
\hline Calcium & 1.03 & 0.88 & 1.03 & 0.88 \\
\hline Phosphorus & 0.65 & 0.61 & 0.65 & 0.61 \\
\hline Methionine $* * *$ & 0.45 & 0.39 & 0.45 & 0.39 \\
\hline Lysin*** & 1.37 & 1.12 & 1.37 & 1.12 \\
\hline Arginine $e^{* * *}$ & 1.51 & 1.28 & 1.51 & 1.28 \\
\hline
\end{tabular}

*Chemical analysis at the Laboratory of Nutrition and Feed Science, Faculty of Animal and Agricultural Sciemces, Diponegoro University (2016); ${ }^{* *}$ Calculated value based on the formula of Carpenter and Clegg (1965); ***Calculated value based on Table of National Research Research Council (1994)

with a small portion of diet based on the treatment level and given in the morning at 05.00 am daily in order to ensure the feed containing Lactobacillus sp. can be completely consumed. Other portion of feed without Lactobacillus sp. were provided thereafter to fulfill the amount of daily requirement.

\section{Experimental Design}

The present experiment was assigned in a completely randomized design with 8 treatments and 4 replications (6 birds each). Dietary treatment were as follows : $21 \%$ intact protein diet (T0), 18\% intact protein diet (T1), 21\% microparticle protein diet (T2), 18\% microparticle protein diet (T3), T0+Lactobacillus sp. at $1.2 \mathrm{ml}$ (T4), T1+Lactobacillus sp. at $1.2 \mathrm{ml}$ (T5), $\mathrm{T} 2+$ Lactobacillus $\mathrm{sp}$. at $1.2 \mathrm{ml}$ (T6), $\mathrm{T} 3+$ Lactobacillus sp. at $1.2 \mathrm{ml}$ (T7). One $\mathrm{ml}$ was equal to $10^{8} \mathrm{cfu}$.

\section{Research Parameters}

Parameters measured were total ileal LAB, Coliform and $\mathrm{pH}$, rate of passage, daily body weight gain (DWG) and also carcass weight. Total $\mathrm{LAB}$ and Coliform were measured according to total plate count (TPC) based on the method of Fardiaz (1993). Potential hydrogen (pH) 
measurement using $\mathrm{pH}$ meter. Rate of passage was determined using ferry oxide $\left(\mathrm{Fe}_{2} \mathrm{O}_{3}\right)$ at 0 , $03 \%$ as an indicator to make sure that the time of excreta dropping can be exactly observed. Daily body weight gain was calculated based on the difference between the final body weight and the initial weight divided by the duration of observation. Carcass weight obtained after chickens were slaughtered and cleaned up from the feathers, legs, head and viscera.

\section{Statistical Analysis}

Data were subjected to analysis of variance and followed by Duncan multiple range test at 5\% probability when the treatment indicated significant effect.

\section{RESULTS AND DISCUSSION}

The results showed that Lactobacillus sp. inclusion at $1.2 \mathrm{ml}$ into microparticle protein diet significantly $(\mathrm{P}<0,05)$ increased ileal lactic acid bacteria (LAB) population (Table 2) and daily body weight gain (Table 3 ), but decreased total ileal Coliform, and slowed down the rate of passage (Table 2). However, carcass meat was not significantly affected by treatments (Table 3 ). The ileal lactic acid bacteria (LAB) in $\mathrm{T} 4$ to $\mathrm{T} 7$ treatments showed the highest value compared to other treatments (T0 to T3) due to the addition of Lactobacillus sp. at $1.2 \mathrm{ml}$. Lactobacillus sp. is known to have ability to ferment soybean oligosaccharide derived from soybean meal microparticle which produced lactic acid as well as short chain fatty acid (SCFA). Descriptive evaluation indicated the higher SCFA values in T7, namely 55.62, 29.61 and $16.24 \mathrm{mmol} / \mathrm{L}$ compared to T0 was 17.88, 10.63 and 10.03 $\mathrm{mmol} / \mathrm{L}$ for acetate, propionate, and butirate, respectively, (Table 2). These metabolite products brought about the decrease in ileal $\mathrm{pH}$ due to inclusion of Lactobacillus sp. (T4, T5, T6, and T7 was $6.05,6.00,5.45$ and 5.75 , respectively) (Table 2) irrespective of dietary protein, and finally increased LAB population. Harimurti et al. (2007) showed that Lactobacillus was able to survive at the low gastrointestinal tract $\mathrm{pH}$ of chicken, therefore this condition implicated to the increasing population of endogenus lactic acid bacteria. On the other hand, decreased total pathogenic bacteria, in this case Coliform. Addition of Lactobacillus sp. $(1.2 \mathrm{ml})$ was assumed to have a more dominant effect when combined with microparticle protein diet. However, when diet with both intact protein and microparticles without Lactobacillus sp. were fed

Table 2. Intestinal Bacteria Population, $\mathrm{pH}$ and Rate of Passage in Broiler Chicken Fed Microparticle Protein Added with Lactobacillus sp.

\begin{tabular}{lcccccccc}
\hline \multirow{2}{*}{ Variables } & \multicolumn{7}{c}{ Treatments } \\
\cline { 2 - 9 } & T0 & T1 & T2 & T3 & T4 & T5 & T6 & T7 \\
\hline $\begin{array}{l}\text { Total ileal lactic acid } \\
\text { bacteria (LAB), } 10^{8} \\
\text { cfu/g }\end{array}$ & $1.75^{\mathrm{b}}$ & $2.37^{\mathrm{b}}$ & $2.55^{\mathrm{b}}$ & $2.50^{\mathrm{b}}$ & $3.82^{\mathrm{a}}$ & $3.72^{\mathrm{a}}$ & $3.87^{\mathrm{a}}$ & $4.55^{\mathrm{a}}$ \\
$\begin{array}{l}\text { Total ileal Coliform, 10 } \\
\text { cfu/g }\end{array}$ & & & & & & & & \\
Ileal pH & $5.9^{\mathrm{a}}$ & $4.3^{\mathrm{b}}$ & $2.7^{\mathrm{c}}$ & $2.8^{\mathrm{c}}$ & $2.4^{\mathrm{cd}}$ & $2.2^{\mathrm{cd}}$ & $1.8^{\mathrm{cd}}$ & $0.8^{\mathrm{d}}$ \\
Rate of passage, min & $6.72^{\mathrm{a}}$ & $6.70^{\mathrm{a}}$ & $6.52^{\mathrm{ab}}$ & $6.45^{\mathrm{ab}}$ & $6.05^{\mathrm{abc}}$ & $6.00^{\mathrm{bc}}$ & $5.45^{\mathrm{c}}$ & $5.75^{\mathrm{c}}$ \\
Short chain fatty acid & $180.1^{\mathrm{b}}$ & $188.2^{\mathrm{b}}$ & $240.2^{\mathrm{a}}$ & $245.9^{\mathrm{a}}$ & $245.0^{\mathrm{a}}$ & $240.0^{\mathrm{a}}$ & $267.9^{\mathrm{a}}$ & $284.9^{\mathrm{a}}$ \\
(SCFA), mmol/L & & & & & & & & \\
Asetat & & & & & & & & \\
Propionat & 17.88 & 20.78 & 21.97 & 33.90 & 33.70 & 33.15 & 52.73 & 55.62 \\
Butirat & 10.63 & 12.37 & 12.08 & 19.69 & 20.53 & 23.53 & 25.69 & 29.61 \\
\hline
\end{tabular}

${ }^{\mathrm{a}-\mathrm{d}}$ Mean values in the same raw followed by different superscript indicate significant difference $(\mathrm{P}<0.05)$ 
Table 3. Productivity in Broiler Chicken Fed Microparticle Protein Added with Lactobacillus sp.

\begin{tabular}{lcccccccc}
\hline \multirow{2}{*}{ Variables } & \multicolumn{7}{c}{ Treatments } \\
\cline { 2 - 9 } & T0 & T1 & T2 & T3 & T4 & T5 & T6 & T7 \\
\hline $\begin{array}{l}\text { Daily body weight } \\
\text { gain, g/bird/day }\end{array}$ & $27.4^{\mathrm{b}}$ & $27.9^{\mathrm{b}}$ & $28.2^{\mathrm{b}}$ & $30.9^{\mathrm{ab}}$ & $30.6^{\mathrm{ab}}$ & $31.8^{\mathrm{ab}}$ & $31.09^{\mathrm{ab}}$ & $34.0^{\mathrm{a}}$ \\
\begin{tabular}{l} 
Carcass weight, g \\
\hline a-b Mean values in the same raw followed by different superscript indicate significant difference $(\mathrm{P}<0.05)$
\end{tabular}
\end{tabular}

did not affect the population of LAB. The results of the present study were consistent with the previous finding (Krismiyanto et al., 2014) that feeding normal level of intact protein diet added with prebiotic inulin showed the increase in LAB population. Similarly, Faradilla (2015) reported that a combination of inulin from dahlia tuber at $1.2 \%$ and Lactobacillus sp. at $1.2 \mathrm{ml}\left(10^{8} \mathrm{cfu} / \mathrm{ml}\right)$ produced the highest LAB amount compared to other treatments combination. The improved bacterial balance modulates the better intestinal health and it can be associated with the higher body resistance and productive performance.

Lactic acid bacteria (LAB) is also produce other metabolite such as bacteriocins that could be able to inhibit pathogenic bacterial growth. Lactobacillus sp. at $1.2 \mathrm{ml}$ could compete with pathogenic bacteria such as Coliform in the ileum $\left(5.9 \times 10^{6} \mathrm{cfu} / \mathrm{g}\right.$ in T0 vs. $0.8 \times 10^{6} \mathrm{cfu} / \mathrm{g}$ in T7, Table 2), so that Coliform population substantially decreased (Table 2). Chichlowski et al. (2007) reported that Lactobacilli can prevent attachment of pathogenic bacteria such as E.coli and Salmonella on the intestinal lumen. The mechanism of probiotics work in altering the physical micro environment of the intestinal tract and inhibit pathogenic bacteria growth can be expalined via two ways. First, probiotic organism competes with pathogens for nutrient, thus preventing them from acquiring energy for growth and function of gastrointestinal. Second, as it has been discussed previously that probiotics produce a variety of organic acid such as SCFA and lactic acid as an apart of their metabolic activity. Organic acids produced by the prebiotic bacteria could decrease $\mathrm{pH}$ of the gut and inhibit the survival of pathogenic bacteria such as E. coli and Salmonella (Haryati, 2011).

In relation to SCFA production which is attributable to fermentative activity of
Lactobacillus sp. addition is accomplished by the increase in intestinal LAB population. One mechanism with regard to the important interference of oligosaccharides derived from soybean meal called as soybean oligosaccharide may provide protection against harmful microorganism by substituting the soluble receptor analogues. In case of the present study, specific oligosaccharide in the form of soybean oligosaccharide can be obtained from the soybean meal treated with ultrasonic bath. Ultrasonic bath treatment did not only change intact protein to be microparticle but also lowered particle size of soybean oligosachharide causing more available either to deceive pathogenic bacteria through receptor substitution or to be function as "food source" for Lactobacillus sp. Reducing harmful bacteria to be vulnerable by inhibiting the formation of fimbriae and other membrane-based adenosines can be an effective control of digestive tract and microbial colonization in the mucosal tissue. The specificity of mucosal attachment provides potential control of gastrointestinal through the function of specific oligosaccharide stracture (Ouwehand and Vaughan, 2006). Decreasing $\mathrm{pH}$ and increasing population of LAB due to the fermentation effect of soybean oligosaccharide provided an impact on medium viscosity of digesta and thus slowed down the rate of passage (180.1 $\mathrm{min}$ in T0 vs. $284.9 \mathrm{~min}$ in T7, Table 2). Potential hydrogen $(\mathrm{pH})$ can be associated with the rate of passage (Hetland et al., 2004). Further effect is that the rate of passage is closely related to nutrient digestibility because the slower rate of passage the higher nutrient digestibility. This condition was also supported by feeding effect of microparticle protein which can assumed that smaller diet particle can be more effectively attached by digested enzyme.

The increased lactic acid bacteria (LAB) and the decreased Coliform populations were also 
supported by the slower rate of passage lead to healthier intestinal of the chicken and better growth of the villi. The better villi growth as an indication of intestinal health improvement was attributable to bacteriocin produced by lactic acid bacteria to suppress the growth of pathogenic bacteria at the competitive state in the small intestine (competitive exclusion) (Dicks and Bones, 2010). As a comparison, Adil et al. (2010) and Jamilah et al. (2014) reported that organic acids, such as citric acid, had a positive effect on the development and growth of intestinal villi, which leads to the increased nutrient absorption. The higher intestinal villi, the more nutrients can be absorbed due to the wider surface of digestive area. This phenomenon was consistent with those previously discussed that the decreased pathogenic bacteria population brought about healthier gastrointestinal and provided a positive impact on intestinal villi growth which fasilitated the more nutrients absorption to accelerate body weight (Faradilla, 2015). The mechanism as described above is the important factor to increase protein supply for body protein deposition which leads to the increase in body weight. Suthama et al. (2010) indicated that meat protein deposition or meat protein mass was an indicator of quality broiler growth, depending on the differences in protein synthesis compared to protein degradation. Increased protein intake or supply is also supported by the slower rate of passage because the longer digesta spent in the intestine is assumed to be higher nutrient digestibility, especially protein.

The results of this study suggested that the increase in protein digestibility which supported the higher meat protein mass was closely related to daily weight gain. A comparative finding (Fajrih et al., 2014) revealed that crossbred local chickens fed normal level of intact protein diet with added prebiotic inulin of dahlia tuber at $1.2 \%$ increased health status since heterophyl/lymphocyte ratio decreased and bursa fabricius weight increased, and improved body weight gain. It can, therefore, be assumed that effectiveness of natural feed additive supplementation, such as probiotic bacteria as well as prebiotic substances, can modulate the balance of intestinal microbes, depending on the birds strain, dietary protein level and condition. Clear phenomenon had been proved in crossbred Indonesian local chickens given reduced protein diet $(18 \%$ vs. 20\%) with the inclusion of Lactobacillus $s p$. at 1,2 $\mathrm{mL}$ improved productive characteristics and performance. The increased meat protein mass and breast meat color (Abdurrahman et al., 2016a), and the decreased fat mass and cholesterol of meat (Abdurrahman et al., 2016b) were the parameters determaining the quality of productive performances due to probiotic supplementing effect. Therefore, a positive effect of Lactobacillus sp. inclusion into the diet composed of microparticle protein, although with reduced protein content, was indicated in the present study.

\section{CONCLUSION}

Inclusion of Lactobacillus sp. at $1.2 \mathrm{~mL}$ into the lower (18\%) microparticle protein diet can increase the population of lactic acid bacteria and daily weight gain, but decrease total ileal Coliform with slower rate of passage in broiler chickens.

\section{REFERENCES}

Abdurrahman, Z.H., Y. B. Pramono and N. Suthama. 2016a. Feeding effect of inulin derived from dahlia tuber combined with Lactobacillus sp. on meat protein mass of crossbred kampong chicken. J. Indonesian Trop. Anim. Agric. 41(1):37-44.

Abdurrahman, Z.H., Y. B. Pramono and N. Suthama. 2016b. Meat characteristic of crossbred local chicken fed inulin of dahlia tuber and Lactobacillus sp. Med. Pet.39(2): 112-118.

Adil, S.,T. Banday, G.A. Bhat, M.S. Mir and M. Rehman. 2010. Effect of dietary supplementation of organic acids on performance, intestinal histomorphology and serum biochemistry of broiler chicken. Vet. Med. Int. 10:1-7.

Carpenter, K.J., and K.M. Clegg. 1965. The metabolizable energy in poultry feeding stuff in relation to their chemical composition. J. Sci. Food Agric. 7(1):45-51

Chichlowski, M., J. Croom, B.W. McBride, G.B. Havenstein and M.D. Koci, 2007. Metabolic and physiological impact of probiotics or direct-fed-microbials on poultry: a brief review of current knowledge. Int. J. Poult. Sci. 6 (10): 694-704.

Dicks, L.M.T. and M. Botes. 2010. Probiotic lactic acid bacteria in the gastrointestinal tract: health benefits, safety and mode of action. Beneficial Microb. 1(1):11-29. 
Fajrih, N., N. Suthama and V. D. Yunianto. 2014. Body resistance and productive performances of crossbred local chicken fed inulin of dahlia tubers. Med. Pet. 37(2):108114.

Faradilla, S. 2015. Pemberian Kombinasi Inlin Umbi Dahlia dan Lactobacillus sp. terhadap Perkembangan Mikroba Usus dan Ketahanan Tubuh Ayam Kampung Persilangan. Tesis. Program Pasca Sarjana Fakultas Peternakan dan Pertanian Universitas Diponegoro, Semarang

Fardiaz, S. 1993. Analisis Mikrobiologi Pangan. PAU Pangan dan Gizi. IPB. Bogor.

Harimurti, S., S. R. Endang., Nasroedin and Kurniasih. 2014. Bakteri asam laktat dari intestin ayam sebagai agensia probiotik. Anim. Prod. 9(2):82-91.

Haryati, T. 2011. Probiotik dan prebiotik sebagai pakan imbuhan nonruminansia. Wartazoa. 21(3):125-132.

Hetland, H. M. Choct and B. Shivus. 2004. Role of insoluble non-starch polysaccharides in poultry nutrition. World's Poult. Sci. J. 60:415-422.

Jambrak, A.R., T.J. Mason, V. Lelas, L. Paniwnyk and Z. Herceg. 2014. Effect of ultrasound treatment on particle size and molecular weight of whey proteins. J. Food Eng. 121: 15-23.

Jamilah, N. Suthama and L.D. Mahfudz. 2013. Performa produksi dan ketahanan tubuh broiler yang diberi pakan step down dengan penambahan asam sitrat sebagai acidifier. J. Ilmu Ternak Vet. 18(4):251-257.

Krismiyanto, L., N. Suthama and H.I. Wahyuni. 2014. Feeding effect of inulin derived from
Dahlia variabilis tuber on intestinal microbes in starter period of crossbred native chickens. J. Indonesian Trop. Anim. Agric. 39(4):217-223.

Mingbin, L.V., L. Yan, Z. Wang, A. Sha, W. Miaomiao and L.V. Zunzhou. 2015. Effect of feed from and feed particle size on growth performance, carcass characteristics and digestive tract development of broiler. Anim. Nutr. 1(3):252-265.

National Reserach Council. 1994. Nutrient Requirements of Poultry. $9^{\text {th }}$ Ed. National Academy Press, Washington DC.

Ouwehand, A.C., and E.E. Vaughan. 2006.Gastrointestinal Microbiology. Taylor and Francis Group. $1^{\text {st }}$ Ed. New York. London.

Pan D. and Z. Yu. 2014. Intestinal microbiome of poultry and its interaction with host and diet. Gut Microbes. 5(1): 108-119.

Roberfroid, M., G. R. Gibson, L. Hoyles, A. L. McCartney, R. Rastall, I. Rowland, D. Wolvers, B. Watzl, H. Szajewska, B. Stahl, F. Guarner, F. Respondek, K. Whelan, V. Coxam, M. J. Davicco, L. Leotoing, Y. Wittrant, N. M. Delzenne, P. D. Cani, A. M. Neyrinck and A. Meheust. 2010. Prebiotic effects: metabolic and health benefits. Br. J. Nutr. 104(S2): S1-S63.

Suthama, N., H. I. Wahyuni and I. Mangitsah. 2010. Laju pertumbuhan berdasarkan degradasi proten tubuh pada ayam kedu dipelihara ex situ Prosiding Seminar Nasional Tentang Unggas Lokal ke-IV. Semarang 7 Oktober 2010. Fakultas Peternakan Universitas Diponegoro, Semarang. P. 138-146. 